\title{
Hormone use in food-animal production: Dietary exposure of consumers and public health significance
}

\author{
Jelka Pleadin \\ Croatian Veterinary Institute, Savska Cesta \\ 143, 10000 Zagreb, Croatia \\ Corresponding author: \\ Jelka Pleadin \\ Phone: +38516123626 \\ Fax: +38516123670 \\ E-mail address: pleadin@veinst.hr
}

\begin{abstract}
Hormones are chemical substances naturally secreted in the body that regulate a wide range of physiological functions. However, during the last decades many cases of their illegal anabolic use in farm animals, aiming to obtain higher yields and profits in livestock production, have been documented. Given that these substances are carried over into body fluids and edible tissues, consumers may experience their impact through daily consumption of different products of animal origin, especially milk, meat and their products. Since many toxic effects of both natural and synthetic hormones have been evidenced, their use as an animal growth promoter is banned by the European Union. Insofar, a unique solution as to how to control the abuse of natural hormones in farm animals has not been found. Further research is needed to determine their natural levels in food in dependence on many factors of influence. Systematic monitoring of hormonal substances at all critical points of food production "from field to table" is necessary, together with continuous development of modern analytical methods in order to prevent hormone abuse and protect consumer health.
\end{abstract}

Keywords: natural and synthetic hormones, food of animal origin, dietary exposure, toxic effects, consumers.

\section{INTRODUCTION}

Hormones are chemical substances naturally secreted in human and animal body, which act as messengers, triggers and modulators of key life-supporting processes. Hormonal effects induced in human body vary dependent on a number of factors, such as host gender and age, but also the environment. Main physiological effects of these substances include maturation of gonads, particularly important during foetal development, and the appearance of secondary sex characteristics during puberty, accompanied by an increase in bone density, muscle mass and muscle strength. Hormones are often classified based on their synthesising organs, so that one distinguishes between adrenal steroids secreted by the adrenal cortex and sex hormones produced by the ovaries and testicles. However, this distinction is not exclusive, since the adrenal cortex also secretes sex hormones, albeit to a lesser extent than the gonads, while under abnormal circumstances ovaries may produce adrenal steroids, too.

Hormones have been exogenously applied to animals and humans in order to obtain certain health benefits. However, these substances can be abused in animals intended for food production in order to improve the average weight gain and the meat/fat ratio through increased nitrogen retention, increased protein synthesis and enhanced degradation of adipose tissue [1]. In the past, numerous cases of illegal animal treatment aiming to achieve higher yields and profits in livestock production have been documented, pointing out that hormones are one of the most used, but also most controversial veterinary drugs [2,3]. Data obtained during the course of mandatory state-scale programmes carried out across the EU member states, have shown the frequency of illicit use of hormonal substances to amount to even 5 - 15\% [4].

Subsequent to animal treatment with anabolic hormone doses, these substances get to be transferred into edible tissues and body fluids (e.g. milk, meat, fat), so that they are present in food and thus pose as a direct consumer health risk [5-9]. Of note, even though therapeutic administration of certain natural steroid hormones in the livestock production sector has been approved, it is very difficult to distinguish such a use from an illicit use for anabolic purposes and to follow up residues of these hormones in food of animal origin, since their levels vary dependent on numerous fac- 
tors of influence [10-12]. This is the exact reason why a unique solution as to how to control the use and abuse of exogeneous natural hormones in farm animals hasn't been found yet.

This review article brings the overview of knowledge on natural and synthetic hormones gathered insofar, this is to say, on anabolics and their use in foodproduction animals, the presence of their residues in food of animal origin, and consumer exposure. On top of that, legal frame and measures taken to control and contain the abuse of these substances in order to be able to vouch for food and consumer safety shall be discussed, as well.

\section{The use of hormones for anabolic purposes}

The group of hormones acting as anabolic growth promoters includes both compounds that naturally occur in animal body and synthetic chemicals that mimic the action of their natural counterparts. Apart from oestrogenic, androgenic and progestogenic compounds, stilbene, thyrostatic, corticosteroid and beta-adrenergic compounds have been recognised as well, all of the aforementioned being used both individually or in efficient combinations [4,13-16]. The meat industry has widely used anabolic hormones to quickly get larger quantities of meat, decrease inputs and reduce production costs, but also to obtain leaner meat preferred by modern consumers. The efficiency of animal growth promotion depends on animal breed, age, reproductive status and mode of hormone administration; it is believed that the use of the latter hormones may increase the growth of farm animals by more than $20 \%$ [17].

In the last decades, the analyses performed on meat samples retrieved from butcher shops and supermarkets across the European Union have proven numerous cases of illicit hormone use [4]. The study carried out in the EU during 1994 in randomly chosen consumer population, the analyses of 1,183 pork steak samples revealed the traces of as many as 17 androgenic and 2 gestagenic hormones in $1.6 \%$ samples [18]. The study of the same design, carried out in the USA in 1999 on 103 beef samples, unmasked melengestrol acetate traces in roughly $75 \%$ of the samples, while approximately $20 \%$ of the samples showed traces of trenbolone. Zeranol or other hormones failed to be found $[19,20]$.

As observed by the EU National Reference Laboratories (NRLs), the number of active compounds is very high and changes continuously over the last decades. Oestrogenic, gestagenic and androgenic compounds, as well as thyrostatic, corticosteroid and $\beta$-agonistic ones, are used alone or in form of growth-promoting "cocktails" composed of several hormones in low concentrations, which makes their detection even more difficult. Their use as growth-promoting substances in animal breeding is banned by the European Union, while the presence of their residues is monitored un- der surveillance programs defined by Directives 96/22/ EC [21], 2008/97/EC [22] and 2003/74/EC [23]. These anabolic steroids are included into the Group A substances under Annex I to the Directive 96/23/EC [24], which addresses growth-promoting agents abused in animal fattening and unauthorized substances with no maximum residue limit (MRL). In this regard, a zero-tolerance policy has been adopted and special analytical requirements have been stipulated. The only exception from the above are natural sex hormones, coming as a result of physiological endogenous secretion, whose analytical distinction from their exogenous counterparts is virtually impossible $[1,12,25]$.

Proven anabolic effects of hormones referred to above have gone in favour of "black marketing" of these substances in the livestock production. At the same time, therapeutic use of certain hormones for veterinary purposes is permitted. Contrary to the European legislation, some countries, e.g., the USA, Canada, Australia, New Zealand and some countries in South America, Asia and Africa, have granted the use of certain hormonal substances with anabolic effect as fattening agents, because the local authorities assessed this usage as risk-free [26].

\section{Toxic effects on human health}

Given that exogeneous hormones mimic body effects of their endogenous counterparts, their entry into an organism may affect hormonal balance of the human body and disturb its natural functions. As with any other natural or synthetic chemical, hormone overexposure can be toxic $[16,27,28]$, while their presence in foodstuffs may affect sensitive consumer population even more severely. As for the natural sex hormones, it seems that their everyday endogenous production and exogeneous intake via food represent the key points of risk assessment when it comes to the adjudication of human toxicity. Whereas the safety level hasn't been established yet, unnecessary exposure of children and foetuses to exogeneous natural or synthetic hormones present in food even in very low doses, should be avoided by all means [29].

Current growing trends in the incidence and prevalence of reproductive disorders and cancers are often linked to exogeneous steroids taken via food. Data have shown that maternal consumption of beef containing higher testosterone levels may affect testicular development in utero and impair reproductive abilities of a grown man [30]. Courant et al. [31] established that cow milk contains substantial amounts of hormones and may therefore represent a significant source of dietary exposure to these substances. Milk consumption has been associated with a higher risk of premature menarche [32], the development of ovarian, prostate and breast cancer, and numerous reproductive disorders [32-35]. 
In children, even slight variations in exogeneous steroid hormone blood levels may seriously affect their development during puberty, and even represent the grounds for health issues during adult life [36]. Several epidemiological studies performed in the last decades documented a premature puberty tendency, in particular in the USA in which the use of certain hormonebased drugs in food-production animals is allowed; however, this tendency is ever more often witnessed in European countries, too $[36,37]$.

On the other hand, the tendency of increase in incidence of certain types of cancer, such as testicle, breast and prostate cancer, haven't been fully clarified yet, but sex hormones have often been suspected to play the key role in their onset [38-40]. One of the drastic showcases witnessed in the past is the use of diethylstilbestrol (DES), a synthetic oestrogenic drug administered in the sixties and banned upon the discovery that it increases the risk of vaginal cancer in daughters born to DES-treated mothers. Oestrogen exposure is one of the well-established risk factors associated with breast cancer as the most common cancer seen in women $[41,42]$. Furthermore, lung cancer as one of the leading cancer-associated deaths in the USA, is linked to elevated levels of oestradiol, found in female smokers [43]. Oestrogens have also been associated with other types of cancer, such as head \& neck squamous cell cancer (HNSCC) [44].

\section{Food levels and consumer exposure}

Given that natural sex hormones are present in farm animal tissues and body fluids in physiological amounts, and that their presence can come as a consequence of therapeutic use, it is understandable that these substances are to be found in final products, as well. Therefore, food of animal origin generally contains sex hormones, their concentration in final products thereby primarily being influenced by their levels in animals the food is produced from. Industrial processing of raw materials has failed to exhibit any substantial influence on hormone levels in final products, since these substances are thermally stable $[5,45]$.

Table 1 shows the levels of major natural hormones in food of animal origin. However, these data do not enable the distinction between endogenous and exogenous levels and can therefore not be linked to possible abuse by the livestock industry.

Data on daily intake of hormones via food of animal origin are rather scarce. They mostly demonstrate that the concentrations of natural sex hormones in different types of food of animal origin are generally low in virtually all types of analysed foodstuffs as compared to the levels found in human body due to the natural endogenous secretion, so that this route of entry should be considered negligible $[5,11,48]$. However, Courant et al. [31] found that egg and milk cannot be dismissed as negligible sources of oestradiol $(2.2 \pm 0.8$ and $3.1 \pm 2.0$ ng/day, respectively), whereas testosterone exposure comes as a result of meat and/or egg ingestion (12.2 \pm 48.2 and $5.2 \pm 2.3 \mathrm{ng} /$ day, respectively). Of note, should the relative contribution of dietary intake to the daily intake of natural hormones be expressed in percentages, the contribution of food of animal origin, especially that of dairy products, may as well be perceived as fairly high (Table 2 ).

Table 1. Natural hormone levels in different types of food of animal origin

\begin{tabular}{lcccc}
\hline $\begin{array}{l}\text { Food- } \\
\text { stuff }\end{array}$ & $\begin{array}{c}\text { 17ß-Oest- } \\
\text { radiol }\end{array}$ & $\begin{array}{c}\text { Proges- } \\
\text { terone }\end{array}$ & $\begin{array}{c}\text { Testos- } \\
\text { terone }\end{array}$ & $\begin{array}{c}\text { Refe- } \\
\text { rences }\end{array}$ \\
\hline $\begin{array}{l}\text { Bovine } \\
\text { muscle } \\
(\mu \mathrm{g} / \mathrm{kg})\end{array}$ & $0.01-0.9$ & 20.0 & 0.78 & {$[5,11,31]$} \\
\hline $\begin{array}{l}\text { Bovine } \\
\text { fat } \\
(\mu \mathrm{g} / \mathrm{kg})\end{array}$ & 0.2 & 4.55 & 10.95 & {$[5]$} \\
\hline $\begin{array}{l}\text { Porcine } \\
\mathrm{muscle} \\
(\mu \mathrm{g} / \mathrm{kg})\end{array}$ & 0.2 & 1.76 & 0.23 & {$[5]$} \\
\hline $\begin{array}{l}\text { Milk } \\
(\mu \mathrm{g} / \mathrm{L})\end{array}$ & $0.01-0.04$ & 12.5 & 0.12 & {$[5,11,46,47]$} \\
\hline $\begin{array}{l}\text { Butter } \\
(\mu \mathrm{g} / \mathrm{kg})\end{array}$ & $<0.03$ & 141 & $<0.05$ & {$[5]$} \\
\hline $\begin{array}{l}\text { Fish } \\
(\mu \mathrm{g} / \mathrm{kg})\end{array}$ & $<0.03$ & 0.51 & 0.07 & {$[5]$} \\
\hline
\end{tabular}

Table 2. Relative contribution of food of animal origin to the daily intake of natural hormones [49]

\begin{tabular}{lccc}
\hline & \multicolumn{3}{c}{ Relative contribution (rough \%) } \\
\cline { 2 - 4 } & $\begin{array}{c}\mathbf{1 7} \boldsymbol{\beta} \text {-Oest- } \\
\text { radiol and } \\
\text { oestrone }\end{array}$ & $\begin{array}{c}\text { Proges- } \\
\text { terone }\end{array}$ & Testosterone \\
\hline $\begin{array}{l}\text { Meat and } \\
\text { fish }\end{array}$ & $15-20$ & 5 & $20-30$ \\
\hline $\begin{array}{l}\text { Dairy prod- } \\
\text { ucts }\end{array}$ & $60-70$ & 80 & $30-40$ \\
\hline Eggs & $15-20$ & 10 & $15-20$ \\
\hline
\end{tabular}

It should by all means be pointed out that scientific notions on the presence of hormones in food and consumer exposure are subject to constant change, virtually on a daily basis. In order to be able to give as well-substantiated assessment as possible, synergistic effects of a number of various hormonal substances, as well as other toxic substances possibly present in food, should be taken into account. Presence of hormones in food of animal origin and the issues arising on this ground should be perceived holistically, taking into account their total intake into consumer organisms, including that coming from the consumption of meat, milk, fish, eggs and products based on all of the afore- 
mentioned, but also that coming from the consumption of food of plant origin.

\section{Measures and monitoring options}

Analytical techniques used to analyse the presence of hormones may generally be divided into screening and confirmatory ones [50]. Given that one mostly deals with illicit substances and that these analytical procedures are carried out in order to monitor possible illicit use of hormones in farm animals, identification of these substances and confirmation of their presence make use of most demanding confirmatory analytical techniques [51]. The most widely used confirmatory techniques are liquid (LC) and gas chromatography (GC) coupled with double mass spectrometry, which allow for an unquestionable identification based on the mass over ion charge ratio typical of a given substance, as well as for the precise quantification of the latter [16].

During the past few years, many authors have described the application of LC-MS/MS methods for the analysis of anabolic steroids in various biological samples, including urine, serum, hair, kidney and fat [52-54], all validated according to the criteria set out under the Decision 2002/657/CE [50] on banned substances. Although the levels of steroids that accumulate in animal tissues are normally lower than in other matrices, many effective methods of their determination in muscle tissue and sometimes even monitoring of a wide range of anabolic compounds are currently known and utilised $[31,55,56]$. Since the number of growth promoters is high and includes natural and synthetic compounds, the use of multianalyte techniques is becoming ever more interesting [57]. The use of ultra-resolution liquid chromatography techniques (UPLC) coupled with mass spectrometry has been shown to provide rapid separation of analytes, shorten the analyses and improve simultaneous detection of multiple steroids $[56,58]$.

Nevertheless, gathering of solid evidence on the use of natural hormones in food-production animals still poses as an unresolved issue, since exogeneous natural hormones follow the same pathways as do natural hormones biosynthesised by animals, making the detection and corroboration of their exogeneous use/abuse very difficult $[26,59]$. On top of that, studies have shown that bovine exposure to testosterone or oestradiol can result in equal or even lower plasma concentrations of these compounds in comparison with the levels seen as a result of natural secretion $[60,61]$. On the other hand, exogeneous natural hormones are used in form of plane semisynthetic esters prone to swift hydrolysis as soon as they enter the bloodstream, whereupon non-esterized forms indistinguishable from naturally occurring ones are created [62].

\section{CONCLUSIONS}

In order to be able to provide as well-substantiated assessment of consumer exposure as possible, synergistic effects of a number of various hormonal substances, as well as other toxic substances possibly present in food, should be taken into account. Further research should be undertaken in order to investigate into yet noninvestigated hormonal substances, since the "black market" tends to launch novel synthetic hormones and their mixtures containing numerous low-dosed active substances virtually on a daily basis. On top of that, further and continuous development of contemporary analytical techniques capable of detecting these newly launched compounds should be pursued, together with the use of matrices that shall enable the detection of prolonged illicit hormone use. It is necessary to ensure the monitoring of hormone presence at all critical points of food production chain, from farm animals to consumers, and to strive to find a definite and unique legal solution to the problem of controlling the use/ abuse of exogenous natural hormones.

\section{Conflict of Interest Statement}

The author declares no conflict of interest whatsoever.

\section{REFERENCES}

1. Pleadin J, Samardžija M. Hormonally active substances in the food chain from farm animals to consumers.Vet Stanica 2019; 50(6):501-12.

2. Armstrong TA, Ivers DJ, Wagner JR, Anderson DB, Weldon WC, Berg EP. The effect of dietary ractopamine concentration and duration of feeding on growth performance, carcass characteristics, and meat quality of finishing pigs. J Anim Sci 2004; 82:3245-53.

3. Pleadin J, Perši N, Antolović B, Šimić B, Kmetič I. Toksikološki aspekti anabolika u hrani životinjskog podrijetla. Croatian J Food Sci Technol 2011 a; 3:48-56.

4. Stephany RW. Hormonal growth promoting agents in food producing animals. Handb Exp Pharmacol 2010; 195:355-67.

5. Hartmann S, Lacorn M, Steinhart H. Natural occurrence of steroid hormones in food. Food Chem 1998; 62:7-20.

6. Andersson A-M, Skakkebaek NE. Exposure to exogenous estrogens in food: possible impact on human development and health. Eur J Endocrinol 1999; 140:477-85.

7. Anderson DB, Moody DE, Hancock DL. Beta Adrenergic Agonists. In: Pond WG, Bell AW, eds. Encyclopedia of Animal Science. USA: Marcel Dekker, 2005:104-7.

8. Andrée S, Jira W, Schwind K-H, Wagner H, Schwägele F. Chemical safety of meat and meat products. Meat Sci 2010; 86:38-48.

9. Pleadin J, Vulić A, Perši N, Vahčić N. Clenbuterol residues in pig muscle after repeat administration in a growthpromoting dose. Meat Sci 2010; 86:733-7.

10. Pleadin J, Terzić S, Nina P, Vulić A. Evaluation of steroid hormones anabolic use in cattle in Croatia. Biotechnol Anim Husb 2011b; 27:147-59.

11. Pleadin J, Perši N, Vulić A, Vahčić N. 17ß-estradiol u goveđem mesu, mlijeku i krvi: Fiziološke razine i zlouporaba u stočarskoj proizvodnji. Meso 2013; 15:44-9. 
12. Pleadin J. Hormoni u hrani životinjskog podrijetla - prirodna pojavnost ili zlouporaba? Zbornik radova s 10 . međunarodne konferencije Hranom do zdravlja, Osijek, 2018; 119-28.

13. Courtheyn D, Le Bizec B, Brambilla G, De Brabander HF, Cobbaert E, Van De Wiele $M$ et al. Recent developments in the use and abuse of growth promoters. Anal Chim Acta 2002; 473:71-82.

14. Reig M, Toldrá F. Veterinary Drug Residues. In: Nollet LML, Toldrá F, eds. Handbook of processed meats and poultry analysis. Boca Raton: CRC Press, Taylor and Francis Group, LLC 2009:647-64.

15. Pleadin J, Vulić $A$, Perši N. $\beta$-adrenergički agonisti:Tvari s anaboličkim učinkom kod životinja za proizvodnju mesa. Meso 2012; 14:51-7.

16. Pleadin J, Bogdanović T. Chemical hazards in fermented meats. In: Zdolec N., ed. Fermented Meat Products: Health Aspects. Boca Raton: CRC Press, Taylor and Francis Group, LLC 2016:417-49.

17. Meyer HHD. Biochemistry and physiology of anabolic hormones used for improvement of meat production. Apmis 2001; 109:1-8.

18. Remy R, Debeuckelaere W. Residues of growth promoting substances in meat. In: Research in the 12 EU Member States, Association des Consommateurs - Test-Achats SC Report prepared on behalf of the European Commission. 1994.

19. Stephany RW, André F. Results of "hormone" residue analyses of bovine meat and liver imported into the EU and originating from the USA "Hormone Free Cattle Program", Bilthoven. 1999.

20. Stephany RW, André F. Results of "hormone" residue analyses of bovine meat and liver originating from the USA domestic market, Bilthoven. 2000.

21. Council Directive 96/22/EC of 29 April 1996 concerning the prohibition on the use in stockfarming of certain substances having a hormonal or thyrostatic action and of beta-agonists, and repealing Directives 81/602/EEC, 88/146/EEC and 88/299/EEC. OJ L 125, 23/05/1996, p. 3-9.

22. Directive 2008/97/EC of the European Parliament and of the Council of 19 November 2008 amending Council Directive 96/22/EC concerning the prohibition on the use in stockfarming of certain substances having a hormonal or thyrostatic action and of beta-agonists. OJ L 318 , 28/11/2008, p. 9-11.

23. Directive 2003/74/EC of the European Parliament and of the Council of 22 September 2003 amending Council Directive 96/22/EC concerning the prohibition on the use in stockfarming of certain substances having a hormonal or thyrostatic action and of beta-agonists. OJ L 262, 14/10/2003, p. 17-21.

24. Council Directive $96 / 23 /$ EC of 29 April 1996 on measures to monitor certain substances and residues thereof in live animals and animal products and repealing Directives 85/358/EEC and 86/469/EEC and Decisions 89/187/EEC and 91/664/EEC. OJ L 125, 23/05/1996, p. 10-32.

25. Stephany RW, Sterk SS, Van Ginkel LA. Tissue levels and dietary intake of endogenous steroids. An overview with emphasis on 17beta-estradiol. In: Ginkel LAV, Stephany RW, Bergwerff AA, eds. Conference on residues of veterinary drugs in Food, Bilthoven 2004; 111-21.

26. Regal AC, Fente CA. Natural Hormones in Food-Producing Animals:Legal Measurements and Analytical Implications, Food Production - Approaches, Challenges and Tasks, Aladjadjiyan A, ed. ISBN: 978-953-307-887-8,
InTech, Available from: http://www.intechopen.com/ books/food-production-approaches-challenges-andtasks/natural-hormones-in-food-producing-animals-legal-measurements-and-analytical-implications. 2012.

27. Food and Agriculture Organization/World Health Organization (FAO/WHO). Toxicological evaluation of certain veterinary drug residues in food. Estradiol-17 $\beta$, progesterone and testosterone. The Fifty-second meeting of the Joint FAO/WHO Expert Committee in Food Additives (JECFA). WHO Food Aditives Series 43. Food and Agriculture Organization/World Health Organization 2000.

28. Pleadin J, Bogdanović T. Anabolici u proizvodnji mesa - Učinci u farmskih životinja i opasnosti po zdravlje potrošača. Meso 2017; 19:59-67.

29. Bay K, Andersson A, Skakkebaek NE. Estradiol levels in prepubertal boys and girls - analytical challenges. Int J Androl 2004; 27(5):266-73.

30. Swan SH, Liu F, Overstreet JW, Brazil C, Skakkebaek NE. Semen quality of fertile US males in relation to their mothers' beef consumption during pregnancy. Hum Reprod 2007; 22(6):1497-502.

31. Courant F, Antignac J, Laille J, Monteau F, Andre F, Le Bizec $B$. Exposure assesment of preburtal children to steroid endocrine disruptors. Determination of steroid hormones in milk, egg and meat samples. J Agric Food Chem 2008; 56:3176-84.

32. Wiley AS. Milk intake and total dairy consumption: Associations with early menarche in NHANES 1999-2004. PLoS One 2011; 6(2):e14685.

33. Givens DI, Morgan R, Elwood PC. Relationship between milk consumption and prostate cancer: A short review. Nutr Bull 2008; 33:279-86.

34. Melnik BC. Milk - the promoter of chronic western diseases. Med Hypotheses 2009; 72(6):631-9.

35. Ganmaa D, Cui X, Feskanich D, Hankinson SE, Willett WC. Milk, dairy intake and risk of endometrial cancer: A twenty six-year follow-up. Int J Cancer 2012; 130(11):2664-71.

36. Aksglaede L, Juul A, Leffers $H$, Skakkebæk NE, Andersson A. The sensitivity of the child to sex steroids: Possible impact of exogenous estrogens. Hum Reprod Update 2006; 12(4):341-9.

37. Parent A, Teilmann G, Juul A, Skakkebaek NE, Toppari J, Bourguignon J. The timing of normal puberty and the age limits of sexual precocity: Variations around the world, secular trends, and changes after migration. Endocr Rev 2003; 24(5):668-93.

38. Huyghe E, Matsuda T, Thonneau P. Increasing incidence of testicular cancer worldwide: A review. J Urol 2003; 170(1):5-11.

39. Prins GS. Endocrine disruptors and prostate cancer risk. Endocr Relat Cancer 2008; 15(3):649-56.

40. Wigle DT, Turner MC, Gomes J, Parent M. Role of hormonal and other factors in human prostate cancer. J Toxicol Env Heal B 2008; 11(3-4):242-59.

41. Kaaks R, Rinaldi S, Key TJ, Berrino F, Peeters PHM, Biessy C et al. Postmenopausal serum androgens, oestrogens and breast cancer risk: The european prospective investigation into cancer and nutrition. Endocr Relat Cancer 2005: 12(4):1071-82.

42. Yager JD, Davidson NE. Estrogen carcinogenesis in breast cancer. N Engl J Med 2006; 354(3):270-82.

43. Meireles SI, Esteves GH, Hirata R, Peri S, Devarajan K, Slifker $\mathrm{M}$ et al. Early changes in gene expression induced by tobacco smoke: Evidence for the importance of estrogen within lung tissue. Cancer Prev Res 2010; 3(6):707-17. 
44. Shatalova EG, Klein-Szanto AJP, Devarajan K, Cukierman E, Clapper ML. Estrogen and cytochrome P450 1B1 contribute to both early- and late-stage head and neck carcinogenesis. Cancer Prev Res 2011; 4(1):107-15.

45. Rose MD, Shearer G, Farrington WHH. The effect of cooking on veterinary drug residues in food: clenbuterol. Food Addit Contam 1995; 12:67-76.

46. Gaiani R, Chiesa F, Mattioli M, Nanneti G, Galeati G. Androstenedione and testosterone concentrations in plasma and milk of cow throughout pregnancy. J Reprod Fertil 1984; 70:55-90.

47. Zhou H, Qin LQ, Ma DF, Wang Y, Wang PY. Uterotrophic effects of cow milk in immature ovariectomized SpragueDawley rats. Environ Health Prev 2010; 15:162-8.

48. Doyle E. Human Safety of Hormone Implants Used to Promote Growth in Cattle. FRI BRIEFINGS. 2000. Food Research Institute, University of Wisconsin Madison, WI. Available from: https://fri.wisc.edu/files/Briefs_File/hormone.pdf.

49. Adolf T, Eberhardt W, Heseker H, Hartmann S, Herwig A, Matiaske $B$ et al. Lebensmittel- und Nahrstoffaufnahme in der Bundesrepublik Deutschland. In:VERA-Schrtftenreihe, Band XII, Ktibler W, Anders HJ, Heeschen W, eds. Wissenschaftlicher Fachverlag Dr. Fleck, Niederkleen. 1994.

50. Commission Decision 2002/657/EC of 12 August 2002 implementing Council Directive 96/23/EC concerning the performance of analytical methods and the interpretation of results. OJ L 221, 17/08/2002, p. 8-36.

51. Stolker AAM, Brinkman UATh. Analytical strategies for residue analysis of veterinary drugs and growth-promoting agents in food-producing animals - a review. J Chromatogr A 2005; 1067:15-53.

52. Draisci R, Palleschi L, Ferretti E, Lucentini L, Cammarata P. Quantitation of anabolic hormones and their metabolites in bovine serum and urine by liquid chromatography-tandem mass spectrometry. J Chromatogr A 2000; 870(1-2):511-22.

53. Kaklamanos G, Theodoridis GA, Dabalis T, Papadoyannis I. Determination of anabolic steroids in bovine serum by liquid chromatography-tandem mass spectrometry. J Chromatogr B 2011; 879(2):225-9.
54. Shao B, Zhao R, Meng J, Xue Y, Wu G, Hu J, Tu X. Simultaneous determination of residual hormonal chemicals in meat, kidney, liver tissues and milk by liquid chromatography-tandem mass spectrometry. Anal Chim Acta 2005; 548(1-2):41-50.

55. Kaklamanos G, Theodoridis G, Papadoyannis IN, Dabalis T. Determination of anabolic steroids in muscle tissue by liquid chromatography-tandem mass spectrometry. J Agric Food Chem 2007; 55(21):8325-30.

56. Vanhaecke L, Bussche JV, Wille K, Bekaert K, De Brabander HF. Ultra-high performance liquid chromatography-tandem mass spectrometry in high-throughput confirmation and quantification of 34 anabolic steroids in bovine muscle. Anal Chim Acta 2011; 700(1-2):70-7.

57. Yang Y, Shao B, Zhang J, Wu Y, Duan H. Determination of the residues of 50 anabolic hormones in muscle, milk and liver by very-high-pressure liquid chromatographyelectrospray ionization tandem mass spectrometry. J Chromatogr B 2009; 877:489-96.

58. Stolker AAM, Rutgers $P$, Oosterink E, Lasaroms JJP, Peters RJB, Van Rhijn JA et al. Comprehensive screening and quantification of veterinary drugs in milk using UPLCToF-MS. Anal Bioanal Chem 2008; 391(6):2309-22.

59. Duffy E, Rambaud L, Le Bizec B, O'Keeffe M. Determination of hormonal growth promoters in bovine hair: Comparison of liquid chromatography-mass spectrometry and gas chromatography-mass spectrometry methods for estradiol benzoate and nortestosterone decanoate. Anal Chim Acta 2009; 637(1-2):165-72.

60. Scippo M, Degand G, Duyckaerts A, Maghuin-Rogister G, Delahaut $P$. Control of the illegal administration of natural steroid hormones in the plasma of bulls and heifers. Analyst 1994; 119(12):2639-44.

61. Simontacchi C, Perez De Altamirano T, Marinelli L, Angeletti R, Gabai G. Plasma steroid variations in bull calves repeatedly treated with testosterone, nortestosterone and oestradiol administered alone or in combination. Vet Res Commun 2004; 28(6):467-77.

62. Stolker A, Groot M, Lasaroms J, Nijrolder A, Blokland M, Riedmaier I. Detectability of testosterone esters and estradiol benzoate in bovine hair and plasma following pouron treatment. Anal Bioanal Chem 2009; 395(4):1075-87.

\section{Upotreba hormona u proizvodnji hrane za životinje: dijetarna izloženost potrošača i značaj u javnom zdravlju}

\author{
Jelka Pleadin \\ Hrvatski Veterinarski Institut, Savska \\ Cesta 143, 10000 Zagreb, Hrvatska
}

\section{Kratak sadržaj}

Hormoni su hemijske supstance koje se prirodno izlučuju u telu i koje regulišu širok spektar fizioloških funkcija. Međutim, poslednjih decenija su dokumentovani mnogi slučajevi ilegalne upotrebe anabolika kod domaćih životinja radi ostvarivanja većih prinosa i profita u stočnoj proizvodnji. Sobzirom da se ove materije prenose u telesne tečnosti i jestiva tkiva, potrošači mogu biti izloženi njihovom uticaju, posebno usled svakodnevne konzumacije različitih proizvoda životinjskog porekla - mleka, mesa i njihovih proizvoda. Usled mnogobrojnih dokaza o toksičnim efektima prirodnih i sintetičkih hormona Evropska Unija je uvela zabranu njihove upotrebe kao stimulansa rasta životinja. Jedinstveno rešenje kako da se kontroliše zloupotreba prirodnih hormona kod domaćih životinja do sada nije pronađeno. Potrebna su dodatna istraživanja kako bi se utvrdio njihov prirodni nivo u hrani, a on zavisi od mnogih faktora. Takođe, potrebno je sistematsko nadgledanje hormonalnih supstanci na svim kritičnim tačkama proizvodnje hrane "od polja do stola", uz kontinuirani razvoj savremenih analitičkih metoda u cilju sprečavanja zloupotrebe hormona i zaštite zdravlja potrošača.

Ključne reči: prirodni i sintetički hormoni, hrana životinjskog porekla, dijetarna izloženost, toksični efekti, potrošači. 